\title{
Indexação biológica múltipla e RT-PCR para detecção de vírus latentes em macieiras
}

\author{
Fabio N. Silva1, Osmar Nickel², Thor V.M. Fajardo² \& Amauri Bogo ${ }^{1}$ \\ ${ }^{1}$ Departamento de Fitotecnia, Universidade do Estado de Santa Catarina, 88520-000, Lages, SC, Brasil; ${ }^{2}$ Embrapa Uva e Vinho, \\ 95700-000, Bento Gonçalves, RS, Brasil
}

Autor para correspondência: Osmar Nickel, e-mail: nickel@cnpuv.embrapa.br

\begin{abstract}
RESUMO
O objetivo deste trabalho foi avaliar a viabilidade da indexação biológica múltipla de vírus latentes de macieiras em indicadoras lenhosas. O método consistiu na enxertia de cinco espécies de indicadoras e duas borbulhas da cultivar a ser indexada em um único portaenxerto. Concluiu-se que a eficácia e a sensibilidade do método biológico múltiplo é adequada para a detecção confiável de Apple stem grooving virus (ASGV), Apple stem pitting virus (ASPV) e Apple chlorotic leaf spot virus (ACLSV) em programas de limpeza clonal e certificação de matrizes de fruteiras. A RT-PCR confirmou o diagnóstico biológico de ASPV e ASGV. Entretanto, ACLSV diagnosticado pela indicadora LL-S5 não foi detectado por RT-PCR em três dos nove acessos analisados. O gene de proteína capsídica de ACLSV de um dos acessos estudados foi clonado e sequenciado; a região de pareamento dos iniciadores de PCR foi comparada com dados do Genbank como subsídio à interpretação da não amplificaçãode certos isolados de ACLSV.

Palavras-chave: Malus domestica, Apple stem grooving virus, Apple stem pitting virus, Apple chlorotic leaf spot virus, Flexiviridae, gene de proteína capsídica.
\end{abstract}

\section{ABSTRACT \\ Biological multiple indexing and RT-PCR detection of latent viruses in apple plants}

This study aimed to evaluate the suitability of a multiple biological indexing method of latent apple viruses. The method consisted of grafting five indicator species and two buds of the plant to be indexed on to one rootstock. Results showed that the sensitivity and efficacy of the MBI is adequate for reliable detection of Apple stem grooving virus, (ASGV), Apple stem pitting virus (ASPV) and Apple chlorotic leaf spot virus (ACLSV) of mother plant stock in certification programs. Sample analysis by RT-PCR confirmed the results of the diagnosis of ASPV and ASGV by multiple biological indexing. However, it did not detect ACLSV diagnosed by LL-S5 in three out of nine analyzed accessions. The coat protein gene of one of the accessions studied was cloned and sequenced. The annealing sites of primers used in unsuccessful amplification attempts were compared with data of the Genbank to explain the non-amplification of certain ACLSV isolates. Keywords: Malus domestica, Apple stem grooving virus, Apple stem pitting virus and Apple chlorotic leaf spot virus, Flexividae, coat protein gene.

A ocorrência generalizada de viroses latentes de macieiras (Malus domestica Borkh.) causadas por Apple stem grooving virus (ASGV, gênero Capillovirus), Apple chlorotic leaf spot virus (ACLSV, gênero Trichovirus) e Apple stem pitting virus (ASPV, gênero Foveavirus), todos pertencentes à família Flexiviridae, na Região Sul do Brasil, foi relatada anteriormente (Nickel et al., 2001). A infecção é muito comumente latente, embora várias doenças de relevância econômica estejam associadas a estes vírus em espécies frutíferas rosáceas como maçãs, pêras, cerejas e damascos, entre outras. Em combinações de copas e portaenxertos sensíveis, as infecções provocam forte redução

Parte da Dissertação de Mestrado do primeiro autor. Universidade do Estado de Santa Catarina. Lages SC. 2007. da produção, seguida de declínio e morte em poucos anos (Kinnard et al., 1996). O diagnóstico de vírus de plantas lenhosas requer estratégias e métodos específicos devido a fatores como a distribuição desuniforme, o título viral flutuante, o hospedeiro e o isolado viral (Candresse et al., 1995). O método-padrão de indexação de vírus em fruteiras lenhosas é a enxertia individual de cada material a ser indexado e da cv. de indicadora sobre um porta-enxerto, que funciona apenas como suporte para o sistema (International Working Group on Fruit Tree Viruses, 2004). O método implica em manipular plantas enxertadas, geralmente, por meses a anos. Condições ambientais imprevisíveis e a falta de sensibilidade das indicadoras a certos isolados virais podem afetar a expressão de sintomas (James, 1999).

O presente trabalho visou avaliar a viabilidade de um protocolo de indexação biológica múltipla em casa de vegetação dos chamados vírus latentes, que unisse todas 
indicadoras em um único porta-enxerto, reduzindo assim substancialmente custos da indexação biológica, e comparar seus resultados com aqueles da análise molecular por RTPCR. A clonagem e o sequenciamento do gene de proteína capsídica de um isolado de ACLSV, e a comparação da sequência da região de pareamento dos iniciadores, foram realizados como subsídio para explicar a não detecção por RT-PCR de alguns isolados positivos para ACLSV na indexação biológica.

No marco da formação de um banco de germoplasma de maçã foram analisados acessos de macieiras antigas, de fundos de quintais, mantidos na Estação Experimental de Fruticultura Temperada da Embrapa Uva e Vinho em Vacaria-RS, coletados em diversas regiões do Rio Grande do Sul (RS) (acesso A05, Vacaria/RS, aprox. 40 anos; acesso A010, Não-Me-Toque/RS, aprox. 35 anos; acesso A011, Colorado/RS, aprox. 50 anos; acesso A014, Carazinho/RS, aprox. 40 anos; acessos A015 e A018, Muliterno/RS, aprox. 50 anos) todas de origem desconhecida. Três amostras, de aprox. 35 anos, acesso M176 ('Delicious'), acesso M177 ('Golden Delicious') e acesso MR1789 (Malus spp. sem especificação) foram coletadas de banco de germoplasma de Santa Catarina (gentilmente cedidas pelo Dr. A. Pereira, Estação Experimental, Epagri, São Joaquim SC).

Foram utilizadas cinco espécies de indicadoras lenhosas: Malus domestica cvs. Virginia Crab (para ASGV, ASPV), Radiant Crab (ASPV), Lord Lambourne-S5 (ACLSV), Spy 227 (ACLSV, ASPV) e Malus micromalus GMAL 723.a (ASGV). Anteriormente às enxertias, as estacas das indicadoras foram mantidas em câmara fria a $4^{\circ} \mathrm{C}$ durante um mês para acúmulo de horas-frio, favorecendo a brotação. Uma estaca de cada uma das cinco indicadoras, de 5-7 cm de comprimento, foi enxertada, no outono de 2005, em um mesmo porta-enxerto oriundo de sementes de $M$. domestica cv. Gala de um ano de idade e cerca de 70 a $80 \mathrm{~cm}$ de altura. As estacas das indicadoras em cada porta-enxerto foram espaçadas 8-10 cm de distância uma da outra. Na base de cada porta-enxerto foram enxertadas duas borbulhas do material a ser indexado. Cada planta-candidata foi avaliada em porta-enxertos, cada um contendo as cinco indicadoras. Os controles positivos consistiram de isolados de ASPV e ACLSV de uma infecção mista da cv. Braeburn (Vacaria $\mathrm{RS}$ ) e de um isolado de ASGV da cv. Baronesa (Caçador SC) mantidos em banco de isolados virais da Embrapa Uva e Vinho. As plantas foram mantidas em casa de vegetação a temperatura ambiente e avaliadas quinzenalmente durante 2 ciclos vegetativos de primavera por 2 anos.

Extratos de RNA total de cada amostra foram obtidos de $300 \mathrm{mg}$ de tecido de casca de ramos, flores e folhas por adsorção em partículas de dióxido de silício (Sigma-Aldrich S-5631) (Rott \& Jelkmann, 2001) e usados para síntese de cDNA e PCR, utilizando-se os iniciadores ACLSV 7233r: 5'CAGACCCTTATTGAAGTCGAA 3', posição 72137233; ACLSV 6875s: 5` GGCAACCCTGGAACAGA 3', posição 6875-6891; ACLSV 7365r: 5' CTAAATGCAAAGATCAGTCGAC 3', posição 7343-
7365; ACLSV 6784s: 5' ATGGCAGCAGTTCTGAATTTG 3', posição 6784-6805; ACLSV 7429r: 5' CACACTTGAGCACACAACACA 3', posição 74097429; ACLSV 6751s: 5' CAGTTTGCTCGACAGAACCA 3', posição 6751-6770; ASPV 9262r: 5' ATAGCCGCCCCGGTTAGGTT 3', posição 92439262; ASPV 8993s: 5' CTCTTGAACCAGCTGATGGC 3', posição 8993-9012; ASGV 6396r: 5' CTGCAAGACCGCGACCAAGTTT 3', posição 63736396; ASGV 5941s: 5'ATGAGTTTGGAAGACGTGCTTC 3', posição 5641-5663. As condições de desnaturação, pareamento e extensão foram: $\mathbf{A S P V}$ : desnaturação a $95^{\circ} \mathrm{C}$, 10 min., 35 ciclos de amplificação (desnaturação, 1 min. a $94^{\circ} \mathrm{C}$; pareamento, $1 \mathrm{~min}$. a $50^{\circ} \mathrm{C}$; e extensão, $1 \mathrm{~min}$. a $72^{\circ} \mathrm{C}$ ) e uma extensão final a $72^{\circ} \mathrm{C}, 10 \mathrm{~min}$; ASGV: desnaturação a $95^{\circ} \mathrm{C}, 2$ min., 34 ciclos de amplificação (desnaturação, $40 \mathrm{seg}$. a $94^{\circ} \mathrm{C}$; pareamento, 40 seg. a $50^{\circ} \mathrm{C}$; e extensão, 1 min. a $72^{\circ} \mathrm{C}$ ) e uma extensão final a $72^{\circ} \mathrm{C}, 5 \mathrm{~min}$; ACLSV: desnaturação a $94^{\circ} \mathrm{C}, 2$ min., 34 ciclos de amplificação (desnaturação, 40 seg. a $94^{\circ} \mathrm{C}$; pareamento, 50 seg. a $48^{\circ} \mathrm{C}$; e extensão, 40 seg. a $72^{\circ} \mathrm{C}$ ) e uma extensão final a $72^{\circ} \mathrm{C}, 5$ $\min$.

Quando não indicado de outra forma, a clonagem foi executada segundo Sambrook \& Russel (2001) com pequenas adaptações. O fragmento de ACLSV amplificado com os iniciadores 6784s e 7429r, de 645 pb, foi ligado ao vetor pCR 2.1 com o TA Cloning Kit (Invitrogen) conforme instruções do fabricante e a construção foi utilizada para transformar células competentes de Escherichia coli DH10B. $\mathrm{O}$ fragmento de interesse de quatro clones recombinantes foi sequenciado em ambas orientações usando os iniciadores M13 senso e complementar (Invitrogen) em sequenciador automático ABI Prism 3700 (Applied Biosystems). A seqüência obtida foi analisada e comparada com as seqüências do GenBank, utilizando-se a função BLAST do NCBI (http://www.ncbi.nlm.nih.gov).

As indicadoras utilizadas neste estudo desenvolveram os sintomas foliares clássicos de infecção por vírus latentes de macieiras nos controle positivos. Diferenças de brotação observadas entre as indicadoras podem ser atribuídas ao termoperiodismo, uma característica intrínseca das fruteiras de clima temperado, decorrente da exigência de frio determinada pelo genótipo de cada cultivar/espécie de indicadora. Os resultados obtidos neste trabalho com a indexação múltipla de ASGV, ASPV e ACLSV estão contidos na Tabela 1 , que engloba os resultados dos dois períodos de leituras. Concluiu-se que o desempenho do método é adequado em eficácia de detecção, sensibilidade e confiabilidade e similar à indexação simples de dupla enxertia (International Working Group on Fruit Tree Viruses, 2004). Considerando-se o mesmo número de 3 repetições da indexação convencional e 5 espécies de indicadoras, a indexação múltipla tem a vantagem da redução no número de plantas enxertadas em $80 \%$, reduzindo assim o custo da indexação. O segundo período de avaliação confirmou as infecções de ASPV e ASGV já observadas no primeiro 
TABELA 1 - Indexação biológica múltipla em indicadoras lenhosas e por RT-PCR de infecções latentes de Apple chlorotic leaf spot virus (ACLSV), Apple stem pitting virus (ASPV) e Apple stem grooving virus (ASGV) em acessos de macieiras

\begin{tabular}{lcccccccc}
\hline \hline \multirow{2}{*}{ Acessos } & \multicolumn{3}{c}{ Indexação biológica } & & \multicolumn{4}{c}{ RT-PCR } \\
\cline { 2 - 3 } \cline { 6 - 8 } & ASGV & ASPV & ACLSV & & ASGV & ASPV & ACLSV \\
\hline A05 & - & - & - & & & - & - & - \\
A010 & - & + & + & & - & + & - \\
A011 & + & + & + & & + & + & - \\
A014 & + & - & - & & + & - & - \\
A015 & + & + & + & & + & + & - \\
A018 & - & - & - & & - & - & - \\
M176 & - & + & + & & + & + & + \\
M177 & + & + & + & & + & + & + \\
MR1789 & + & + & + & & + & + & + \\
\hline
\end{tabular}

1) Malus domestica cvs. Virginia Crab (ASGV), Radiant Crab (ASPV), Lord Lambourne, seleção LL-S5 (ACLSV), Spy 227 (ASPV) e Malus micromalus GMAL 723.a (ASGV); Tabela engloba dados de leitura de dois ciclos vegetativos e resultados de três repetições por tratamento.

período. O aparecimento dos sintomas de ACLSV somente na segunda enfolhação de LL-S5 pode ser devido à concentração e/ou às características biológicas do isolado viral ou ainda à interação específica do isolado viral com a indicadora (Forsline et al., 1996; James, 1999). Essa reação pode ser explicada pela grande diversidade genética e biológica de ACLSV, que implica na presença de isolados menos virulentos, com sintomas às vezes imperceptíveis na indicadora (Candresse et al., 1995; Cieslinska et al., 1995). A presença do vírus nas gemas usadas como inóculo é determinada tanto pela cultivar como pelo isolado viral e depende de sua capacidade de multiplicação e movimento (Fridlund, 1982). A presença de ASGV no acesso M176, detectado pela RT-PCR (Tabela 1), mas testada negativa em Virginia Crab em duas enfolhações caracteriza um escape natural em sistemas biológicos, resultante da relação isolado viral-indicadora. Em analogia, em estudo de 18 isolados europeus, três isolados de ASGV positivos na indicadora $M$. micromalus foram negativos em Virginia Crab e um isolado de ASGV não foi detectado no teste biológico por nenhuma das duas indicadoras, enquanto todos os quatro isolados foram detectados pela RT-PCR (Kirby et al., 2001; James, 1999). As análises de extratos de ácidos nucléicos totais de casca de ramos e flores viabilizaram resultados reproduzíveis para os três vírus, enquanto os de folhas foram inconsistentes (resultados não mostrados). Utilizando-se os iniciadores 6875s e7233r, considerados de amplo espectro, que flanqueiam um fragmento de 358 pb, não se conseguiu a detecção dos isolados de ACLSV dos acessos A010, A011 e A015, diagnosticados positivos para ACLSV pela indexação biológica em LL-S5 (Tabela 1), apesar da localização das sequências desses iniciadores no gene da proteína capsídica $(\mathrm{CP})$, região melhor conservada entre isolados de ACLSV que determina a baixa diversidade sorológica desse vírus (Candresse et al., 1995). Observação similar foi feita com isolados de Grapevine leafroll-associated virus-2 em videiras (Bertazzon \& Angelini, 2004). Os autores atribuíram o fato à grande variabilidade genética dos vírus e ao consequente não reconhecimento das sequências virais pelos iniciadores, impedindo seu pareamento. Os iniciadores 6875 s e 7233 r amplificaram fragmentos de vários isolados de ACLSV, mas não viabilizaram a amplificação de um isolado polonês de ameixeiras (Cieslinska et al., 1995). Com os pares de iniciadores 7365r/6784s e 7429r/6751s sintetizados com base nas sequências do isolado P863 de ameixeira, número de acesso no GenBank M58152, não ocorreu a amplificação de nenhum dos fragmentos esperados. Entretanto, usando-se o iniciador homólogo 6784s com o complementar 7429r, obteve-se do acesso MR1789, mas não do acesso M176, a amplificação de um fragmento de $645 \mathrm{pb}$ (Figura 1), contendo o gene CP completo (582 pb) do isolado de ACLSV denominado BR1 (número de acesso no GenBank EF138602). Na sequência do gene CP do isolado BR1 constatou-se identidades de 83 a 94\% em nível de nucleotídeos na comparação com isolados selecionados pela base de dados. Com o isolado P863 (número de acesso M58152), do qual se originaram as sequências dos iniciadores 6784s-7429r, a identidade de nucleotídeos da CP do isolado BR1 foi de somente $86 \%$, aproximandose mais (91 a 94\%) de isolados japoneses (números de acesso AB060963, AB060950 e AB060962). Entretanto, os mesmos isolados MO31 (AB060963) e P195 (AB060950) com identidades, respectivamente, de $84 \%$ e $85 \%$ com o fragmento da região não codificante do isolado BR1, não possuem identidade significativa com a sequência do iniciador 7429r (Figura 2). É plausível, portanto, propor

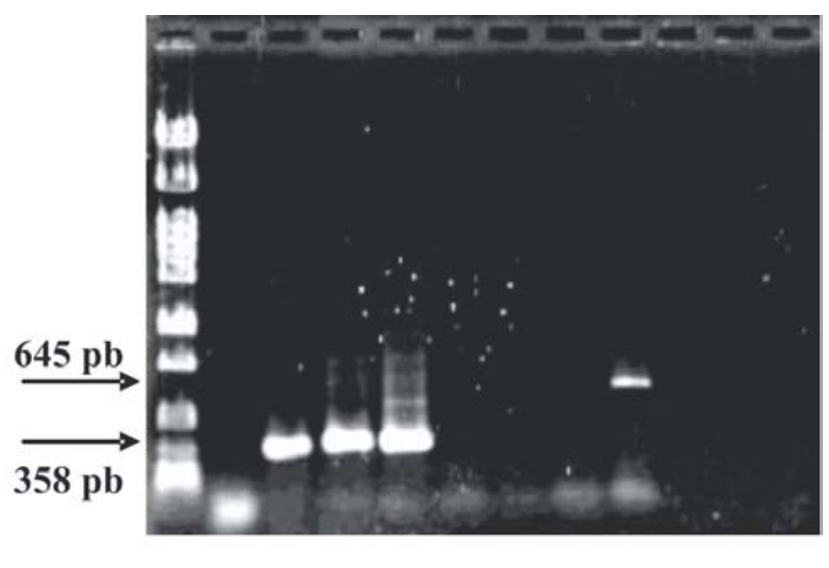

$\begin{array}{llllllllllll}1 & 2 & 3 & 4 & 5 & 6 & 7 & 8 & 9 & 10 & 11 & 12\end{array}$

FIG. 1 - Análise de produtos da RT-PCR por eletroforese em gel de agarose. 1. Marcador molecular Lambda DNA/PstI; 2. Controle negativo (água); 3. Controle positivo (Apple chlorotic leaf spot virus, cv. Braeburn, Vacaria RS); 4. Acesso M176; 5. Acesso MR1789; 2-5. iniciadores 6875s-7233r; 6-9 amostras como em 2-5, iniciadores 6784s-7429r; 10-12 amostras como em 2-5, iniciadores $6751 \mathrm{~s}-7429 \mathrm{r}$. 
A

6784s:
EF138602*:
AB326224:
AJ243438:
M58152 :
AM709777:
AM409322:
AM408891:
D14996:
AB326223:
AJ586638:
AB060961:
AB060958:
AB060950:
AB060962:
AB060963:

ATGGCAGCAGTTCTGAATTTG

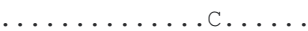

$\ldots \ldots \ldots \ldots \ldots \ldots$

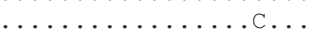

$\ldots \ldots \ldots \ldots \ldots \ldots$

$\ldots \ldots \ldots \ldots \ldots \ldots . A$

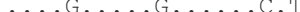

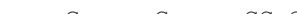

....G....G....CC.C

....G....G..C..CC.

$\ldots \ldots \ldots \ldots \ldots$

...G.....A... .T

...G....G....CC.C

............YY.

$\ldots \ldots \ldots \ldots$
B

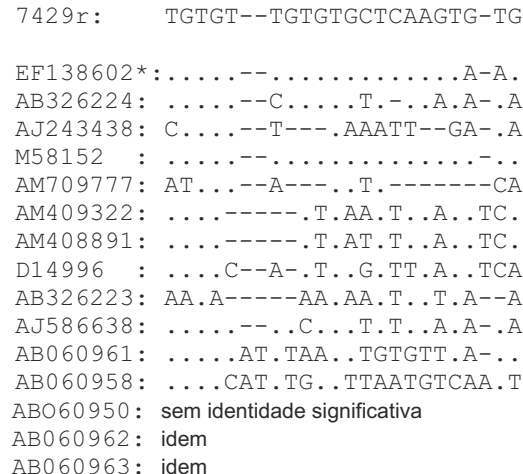

C

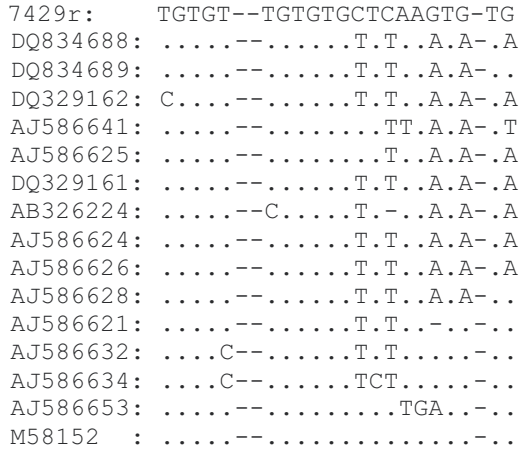

FIG. 2 - Alinhamento de sequências de nucleotídios dos iniciadores $6784 \mathrm{~s}$ e 7429r, utilizados na amplificação do fragmento de 645 nt contendo o gene de CP de ACLSV do isolado BR1 (582 pb), acesso de macieira MR1789; A. Extremidade 5', região de pareamento com 6784s; B. e C., extremidade 3', região de pareamento com 7429r, B. bloco de isolados com alta variabilidade; C. bloco de isolados com baixa variabilidade, respectivamente. * isolado BR1.

que a não amplificação de fragmentos de isolados de ACLSV com a combinação de iniciadores 6784s/7429r seja devida à variabilidade genética desses isolados na região de pareamento com o iniciador 7429r. Enquanto no terminal $5^{\prime}$ do gene $\mathrm{CP}$ as sequências são altamente conservadas (Figura 2A), na extremidade 3' na região de pareamento do iniciador de cDNA formam-se, claramente, 2 grupos de isolados, respectivamente, com baixa e alta identidade com a sequência do iniciador 7429r (Figura 2B-C). A não adequação deste iniciador para a detecção de um grupo de isolados de ACLSV pode redundar em falsos negativos. Entretanto, como nestas análises foram utilizados somente iniciadores patógeno-específicos sem controles internos para amplificação de genes vegetais, os resultados negativos de algumas reações podem, adicionalmente, ser atribuídos à degradação do RNA ou à presença de inibidores da atividade da transcriptase reversa ou da Taq polimerase e não à ausência do patógeno (Menzel et al., 2003).

Se por um lado as restrições aos métodos imunoenzimáticos (ELISA) decorrem, basicamente, da flutuação do título viral, da sazonalidade do diagnóstico e da ocorrência de serótipos (Cieslinska et al., 1995), e, por outro lado, os métodos biológicos são vulneráveis à relação isolado viral vs. indicadora, a variabilidade genética dos isolados virais exige estratégias específicas para evitar falsos negativos no diagnóstico por RT-PCR (Bertazzon \& Angelini, 2004). Conclui-se que o risco de escape é intrínseco a ambos os métodos avaliados. Aliar a indexação biológica múltipla em indicadoras de reação foliar rápida à RT-PCR para casos específicos de certificação de material de elite é uma estratégia factível e econômica para obter-se maior confiabilidade no diagnóstico de vírus latentes de frutíferas rosáceas.

\section{AGRADECIMENTOS}

Os autores agradecem ao Dr. Francisco J.L. Aragão (Embrapa Recursos Genéticos e Biotecnologia, Brasília, DF) pelo sequenciamento dos clones de ACLSV aqui obtidos.

\section{REFERÊNCIAS BIBLIOGRÁFICAS}

Bertazzon N, Angelini E (2004) Advances in the detection of grapevine leafroll-associated virus 2 variants. Journal of Plant Pathology 86:283-290.

Candresse T, Lanneau M, Revers F, Grasseau N, Macquaire G, German S, Malinowski T, Dunez J (1995) An immuno-capture PCR assay adapted to the detection and the analysis of the molecular variability of the apple chlorotic leaf spot virus. Acta Horticulturae 386:136-147.

Cieslinska M, Malinovski T, Zawadzka BJ (1995) Studies on several strains of Apple chlorotic leaf spot virus (ACLSV) isolated from different fruit tree species. Acta Horticulturae 386:63-71.

Forsline PL, Hoch J, Lamboy WF, Hu JS, McFerson JR, Golino DA, Gonsalves D (1996) Comparative effectiveness of symptomatology and ELISA for detecting two isolates of grapevine leafroll on graftinoculated Cabernet Franc. American Journal of Enology and Viticulture 47:239-243.

Fridlund PR (1982) Distribution of chlorotic leaf spot virusinfected buds on various lengths of apple budsticks in successive years. Acta Horticulturae 130:85-88.

International Working Group on Fruit Tree Viruses (2004) Detection of virus and virus-like diseases of fruit trees. Acta Horticulturae 657:575-596.

James D (1999) A simple and reliable protocol for the detection of apple stem grooving virus by RT-PCR and in a multiplex PCR 
assay. Journal of Virological Methods 83:1-9.

Jelkmann W (1994) Nucleotide sequences of Apple stem pitting virus and of the coat protein gene of a similar virus from pear associated with vein yellows disease and their relationship with potex- and carlavirus. Journal of General Virology 75:1535-1542.

Kinard GR, Scott SW, Barnett OW (1996) Detection of apple chlorotic leaf spot and apple stem grooving virus using RT-PCR. Plant Disease 80:616-621.

Kirby MJ, Guise CM, Adams AN (2001) Comparison of bioassays and laboratory assays for apple stem grooving virus. Journal of Virological Methods 93:167-173.

Menzel W, Zahn V, Maiss E (2003) Multiplex RT-PCR-ELISA compared with bioassay for the detection of four apple viruses. Journal of Virological Methods 110:153-157.
Nickel O, Fajardo TVM, Jelkmann W, Kuhn GB (2001) Sequence analysis of the capsid protein gene of an isolate of Apple stem grooving virus, and its survey in southern Brazil. Fitopatologia Brasileira 26:655-659.

Radaelli P, Nickel O, Schons J, Aragão FJL, Fajardo TVM (2006) Diagnóstico biológico e molecular e análise da sequência de nucleotídeos do gene da proteína capsidial de um isolado do Apple stem pitting virus. Fitopatologia Brasileira 31:657-662.

Rott ME, Jelkmann W (2001) Characterization and detection of several filamentous viruses of cherry: adaptation of an alternative cloning method (DOP-PCR), and modification of an RNA extraction protocol. European Journal of Plant Pathology 107:411-420.

Sambrook J, Russel D (2001) Molecular Cloning, A Laboratory Manual. $3^{\text {rd }}$ ed. New York MY. Cold Spring Harbor Laboratory Press.

Recebido 26 Março 2007 - Aceito 18 Janeiro 2008 - TPP 7028

Editor Associado: F. Murilo Zerbini 